\title{
PENGARUH HARGA DAN KUALITAS PRODUK TERHADAP MINAT BELI KONSUMEN PADA PRODUK PEYEK KACANG DIPRODUSEN PEYEK BERKAH BERSAUDARA BOJONG SARI,DEPOK,JAWA BARAT
}

\author{
Wawan Supriyatna ${ }^{1}$, Ade Rachmawan ${ }^{2}$, Zakaria $^{3}$ \\ Dosen01806@unpam.ac.id ${ }^{1}$, dosen02027@unpam.ac.id ${ }^{2}$, \\ dosen02357@unpam.ac.id ${ }^{3}$
}

\begin{abstract}
ABSTRAK
Pandemi covid-19 datang menerjang bagaikan tsunami bagi sendi-sendi bisnis tanpa pandang bulu. Memukul dengan sangat massive dan telak hingga meninggalkan duka akibat gelombang PHK yang tidak terhindarkan. Bisnis yang sudah dijalani puluhan tahun dan tak pernah ada masalah pun tiba-tiba ambruk. Dirumahkan, kondisi tersebut memaksa banyak orang bahkan dari kalangan manajemen kelas menengah, para manajer keatas untuk rela dipotong gajinya atau menjadi korban PHK. Usaha kecil produsen peyek kacang dirintis oleh seorang korban pandemic Covid-19 untuk bertahan dengan segala kebutuhan ekonomi keluarga besarnya dengan nama Berkah Bersaudara. Sejak dibentuk awal Maret lalu, usaha peyek yang dirintis telah banyak membuahkan hasil, tetapi sekitar sebulan belakangan ini mengalami kelesuan dalam hal pemasarannya. Tujuan dari penelitian ini adalah ingin mengetahui pengaruh harga dan kualitas produk terhadap minat beli konsumen pada produk peyek tersebut. Objek pada penelitian ini adalah para pelanggan atau outlet tempat produk peyek Berkah Bersaudara dipasarkan kepada pelanggan, metode penelitian ini menggunakan metode asosiatif pendekatan kuantitatif dengan jumlah sampel sebanyak 67 outlet. Metode pengumpulan data yang digunakan ialah angket kuesioner. Analisis data yang digunakan yaitu analisis regresi linear berganda dan uji asumsi klasik. Hasil dari penelitian tersebut adalah terdapat pengaruh yang signifikan antara harga dan kualitas produk terhadap minat beli konsumen. Luaran yang ditargetkan dalam penelitian ini adalah akan dipublikasikan pada jurnal nasional di Universitas Pamulang.
\end{abstract}

Kata Kunci : harga, kualitas produk, pemasaran, UMKM, minat beli

\section{ABSTRACT}

This study was to analyze the influence between price and product quality on consumer buying interest in the peanut crackers factory Berkah Bersaudara at Bojongsari, DepokWest Java. The covid-19 pandemic has come crashing like a tsunami for business joints indiscriminately. Hitting so massive and badly that it left grief as a result of the inevitable wave of layoffs. A business that has been running for decades and has never had any problems suddenly collapsed. Being sent home, this condition forces many people, even middle-class management, managers-up willing to have their salaries cut or become victims of layoffs. A small peanut crackers producer business was pioneered by a victim of the Covid-19 pandemic to survive with all the economic needs of his extended family with the name Berkah Bersaudara. Since its formation in early March, the peanut crackers project business has yielded many results, but for the past month or so it has experienced sluggishness in terms of marketing. The purpose of this study was to determine the effect of price and product quality on consumer purchase interest in the project peanut crackers product. The objects in this study are the customers or outlets where the Berkah Bersaudara products are marketed to customers. This research method uses an associative 
method with a quantitative approach with a total sample of 67 outlets. The data collection method used was a questionnaire. Data analysis used is multiple linear regression analysis and classical assumption test. The result of this research is there is a significant influence between price and product quality on consumer buying interest.

Keywords : Price, product quality, marketing, SME, buying interest

\section{PENDAHULUAN}

\subsection{Latar Belakang}

Sejak tanggal 14 Maret 2020 Pemerintah telah menetapkan Wabah Corona Virus atau Covid-19 sebagai Bencana Nasional. Status tersebut diumumkan oleh Presiden melalui Kepala Badan Nasional penanggulangan Bencana Doni Monardo di Gedung BNPB. Situasi pandemic memberi banyak ketidak pastian dan membawa banyak dampak terhadap berbagai sektor bisnis atau layanan yang tengah berjalan. Kini, mereka harus memangkas banyak hal untuk menjamin bisnis tetap bertahan dalam jangka panjang. Bisnis memang harus kreatif. Perubahannya terkadang memang begitu cepat. Seperti pada saat situasi pandemi seperti sekarang. Tak pernah ada yang menyangka bahwa ini akan terjadi.

Pandemi COVID-19 telah berdampak sangat besar kepada hampir seluruh pelaku usaha, termasuk startup yang sedang membangun dan mengembangkan bisnisnya. Karena itu untuk menjamin keberlangsungan bisnis, perusahaan wajib melakukan strategi dengan fokus pada kekuatan atau bisnis intinya.

Perubahan strategi perusahaan tentu berdampak ke makroekonomi, namun itu adalah bagian dari resiko yang harus ditanggung, diharapkan pemerintah dapat bertindak menghapuskan hambatan-hambatan birokrasi, menurunkan ego sektoral dan berusaha sekuat tenaga agar ekonomi bisa bangkit kembali. Pemberian bantuan social baik melalui mekanisme Bantuan Presiden, Bantuan Kementrian Sosial, Bantuan Gubernur dan lainnya dirasa cukup membantu masyarakat yang terkena dampak langsung maupun tidak langsung dari pandemic Covid-19 ini.

Usaha kecil produsen peyek kacang dirintis oleh seorang korban pandemic Covid-19 yang terdiri dari Adik dan Kakak yang kebetulan tinggal di suatu area yg berdekatan, tidak dalam satu lingkungan perumahan, tetapi masih dalam radius 1 -2 kilometer untuk bertahan dengan segala kebutuhan ekonomi keluarga besarnya dengan nama Berkah Bersaudara. Sejak dibentuk awal Maret lalu, usaha peyek yang dirintis telah banyak membuahkan hasil, tetapi sekitar sebulan belakangan ini mengalami kelesuan dalam hal pemasarannya. Pada awal bulan Maret 2020, Pak Nanang selaku pemilik usaha melakukan pemasaran produknya ke outlet yang menyediakan kebutuhan makanan sehari - hari dan warung sembako dalam pemasarannya. Outletnya tersebar mulai dari warung nasi seperti warteg, tukang sayur, warung sembako, pedagang soto, tukang bubur dan sebagainya. Tren perkembangannya adalah dari nol outlet menjadi sekitar 135 outlet pada bulan September lalu, lalu menurun sampai dengan 67 outlet di akhir November 2020.

\begin{tabular}{|l|c|c|c|}
\hline No & Bulan & $\begin{array}{c}\text { Jumlah } \\
\text { Outlet }\end{array}$ & Selisih \\
\hline
\end{tabular}




\begin{tabular}{|l|l|l|l|}
\hline 1 & Maret & 32 & 0 \\
\hline 2 & April & 80 & +52 \\
\hline 3 & Mei & 100 & +20 \\
\hline 4 & Juni & 130 & +30 \\
\hline 5 & Juli & 135 & +5 \\
\hline 6 & Agustus & 122 & -13 \\
\hline 7 & September & 89 & -33 \\
\hline 8 & Oktober & 67 & -22 \\
\hline \multicolumn{4}{|l}{} \\
\hline
\end{tabular}

Tabel 1. Pergerakan jumlah outlet peyek Berkah Bersaudara

Objek pada penelitian ini adalah para pelanggan atau outlet tempat produk peyek Berkah Bersaudara dipasarkan kepada pelanggan, metode penelitian ini menggunakan metode asosiatif pendekatan kuantitatif dengan jumlah sampel jenuh sebanyak 67 outlet.

Metode pengumpulan data yang digunakan ialah angket kuesioner. Analisis data yang digunakan yaitu analisis regresi linear berganda dan uji asumsi klasik.

Hasil dari penelitian tersebut adalah terdapat pengaruh yang signifikan antara harga dan kualitas produk terhadap minat beli konsumen. Luaran yang ditargetkan dalam penelitian ini adalah akan dipublikasikan pada jurnal nasional di Universitas Pamulang.

\subsection{Perumusan Masalah}

Perumusan dari penelitian ini adalah:

1. Untuk mengetahui adakah pengaruh harga terhadap minat beli konsumen pada produk peyek tersebut.

2. Untuk mengetahui adakah pengaruh kualitas produk terhadap minat beli konsumen pada produk peyek tersebut.

\subsection{Tujuan Penelitian}

Adapun tujuan dari penelitian ini adalah sebagai berikut:
1. Menganalisa pengaruh harga terhadap minat beli konsumen pada produk peyek tersebut.

2. Menganalisa pengaruh kualitas produk (peyek) terhadap minat beli konsumen pada produk peyek tersebut.

\section{TINJAUAN PUSTAKA}

\subsection{Pentingnya Harga Dalam Pemasaran}

Menurut pendapat ahli, Kotler dan Keller (2016:491), terdapat beberapa tujuan penetapan harga, antara lain :

1. Kemampuan Untuk Bertahan (Survival)

2. Profit Maksimum Saat ini (Maximum Current Profit)

3. Pangsa Pasar Maksimum (Maximum Market Share)

4. Pemerahan Pasar Maksimum (Maximum Market Skimming)

5. Kepemimpinan Kualitas Produk (Product- Quality Leadership)

6. Tujuan-tujuan Lainnya (Other Obejctives)

Dalam hal ini, pemasaran peyek kacang Berkah Bersaudara melakukan penetapan harga pada awal pemasarannya dan penilaian kembali harga yang sudah ditetapkan setelah beberapa bulan melakukan proses penjualan bertujuan untuk bertahan (survive) dan untuk meraih pangsa pasar maksimum.

Pada dasarnya proses penetapan harga yang baik dimulai dengan memahami keseluruhan nilai suatu produk atau jasa yang dibuat dan mempertimbangkan untuk penetapan harga yang dapat menangkap nilai tersebut. Persepsi pelanggan dari nilai produk menetapkan batas atas, harga yang ditetapkan apabila pelanggan merasa bahwa harga yang ditetapkan lebih besar daripada nilai produk, maka mereka tidak akan membelinya.

Penetapan harga berdasarkan nilai menggunakan persepsi nilai dari pembeli, bukan dari biaya penjual, sebagai kunci dari penetapan harga.Perusahaan dapat mengejar salah satu dari dua jenis penetapan harga 
berdasarkan nilai, penetapan harga berdasarkan nilai yang baik termasuk menawarkan kombinasi yang tepat dari kualitas dan layanan yang baik pada harga yang wajar.

Perusahaan yang menggunakan penetapan harga berdasarkan nilai harus menemukan nilai-nilai yang pembeli berikan untuk penawaran kompetitif yang berbeda. Namun, hal itu sering kali sulit untuk mengukur nilai pelanggan yang akan dikaitkan dengan produknya.

Harga sebuah produk atau jasa yang berlaku dalam perusahaan selalu berada di antara tingkat harga yang terkadang dinilai terlalu tinggi untuk menciptakan laba lebih banyak dan tingkat harga yang terlalu rendah untuk membuat banyak permintaaan. Persepsi pelanggan tentang nilai menentukan batas atas harga, sedangkan biaya produksi dari sebuah produk dan biaya tetap perusahaan menetapkan batas bawah harga, bila perusahaan memberikan harga di bawah biaya - biaya tersebut maka perusahaan akan mengalami kerugian.

Pernyataan di atas mengemukakan bahwa Harga merupakan suatu bagian yang penting bagi pembeli dan penjual. Pertukaran barang dan jasa hanya akan terjadi jika penjual dan pembeli telah menyepakati harga. Keputusan harga akan menentukan keberhasilan atau kegagalan bagi perusahaan. Harga juga dirasa sangat penting dalam mengatur perekonomian.Kepentingan terhadap harga telah meningkat.Harga merupakan dasar terbentuknya keuntungan sehingga seluruh perusahaan berusaha memaksimalkannya dengan pengembangan pasar.Permintaan pasar sebagian besar dipengaruhi oleh harga. Harga akan memberikan posisi yang kompetitif pada pasar. Dengan demikian kebijakan terhadap harga merupakan hal yang tidak diragukan lagi sebagai senjata secara khusus dalam sistem perekonomian negara seperti menyempurnakan sumber daya sesuai prioritas yang telah direncanakan sebelumnya.

Begitu pentingnya penetapan harga, pendekatan dalam menetapkan harga sebuah bisa dilakukan dua arah yaitu, pendekatan dari pihak produsen dimana harga tidak boleh lebih rendah dari biaya rata-rata per produk kalau perusahaan ingin memperoleh keuntungan.Selanjutnya pendekatan dari pihak konsumen dimana pada pendekatan ini harga akan membawa dampak ekonomis dan psikologis. Dampak ekonomisnya berkaitan dengan daya beli, sebab harga merupakan biaya (cost) bagi pembeli.Semakin tinggi harga, semakin sedikit produk yang bisa mereka beli.Sebaliknya, semakin rendah harga, semakin banyak produk yang bisa mereka beli. Sedangkan dampak psikologis dalam beberapa kondisi harga rendah menggambarkan kualitas yang rendah sedangkan harga tinggi menggambarkan kualitas yang tinggi.

Karena harga sangat penting artinya bagi bisnis dan perusahaan, maka setiap perusahaan akan melakukan berbagai strategi dalam menetapkan harga yang terbaik. Dalam strategi untuk menetapkan harga, umumnya dibagi berdasarkan jenis produknya, produk baru atau produk yang sudah beredar

\subsection{Pentingnya Kualitas Produk Bagi Perusahaan}

Secara umum, kualitas sebuah produk, dan juga termasuk didalamnya jasa adalah kondisi fisik (dalam jasa kondisi pelayanan atau fasilitas yang ditawarkan), fungsi dan sifat suatu produk baik berupa barang atau jasa, berdasarkan tingkat mutu yang diharapkan seperti durabilitas, reliabilitas, ketepatan, kemudahan pengoperasian, reparasi produk serta asesories lainnya dengan tujuan untuk memenuhi dan memuaskan kebutuhan konsumennya.

Kualitas daripada produk merupakan sebuah kunci memenangkan persaingan. Konsumen ingin mendapatkan produk yang berkualitas sesuai (terkadang menginginkan lebih) dengan harga yang dibayar, walaupun terdapat sebagian masyarakat yang berpendapat bahwa, produk yang mahal adalah produk yang berkualitas. Jika hal itu dapat dilaksanakan oleh perusahaan, maka perusahaan tersebut akan dapat tetap 
JRNAL ПMПAH

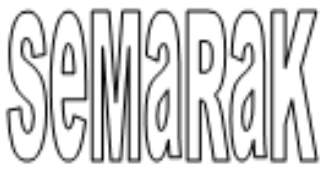

P-ISSN 2615-6849, E-ISSN 2622-3686

Jurnal Semarak,Vol.4,No.2,Juni 2021, Hal (32-37)

@Prodi Manajemen Fakultas Ekonomi Universitas Pamulang

memuaskan para konsumen dan dapat menambah jumlah konsumen.

Kualitas produk suatu hal yang harus diupayakan oleh setiap produsen untuk dapat bersaing dengan baik dipasaran. Adanya hubungan timbal balik antara perusahaan dengan konsumen akan memberikan peluang untuk mengetahui dan memahami kebutuhan dan harapan yang ada pada persepsi konsumen. Maka produsen atau perusahaan penyedia produk dapat memberikan kinerja yang baik untuk mencapai kepuasan konsumen melalui cara memaksimalkan pengalaman yang menyenangkan dan meminimalisir pengalaman yang kurang menyenangkan konsumen dalam mengkonsumsi produk

Kualitas dari produk dapat meningkatkan reputasi perusahaan, sebuah perusahaan yang menghasilkan produk atau jasa yang berkualitas akan mendapat predikat sebagai organisasi yang mengutamakan kualitas, untuk selanjutnya mendapatkan tempat tersendiri dalam benak masyarakat, atau biasa disebut image.

Penurunan biaya yang biasanya dilakukan dengan jalan efesiensi, dengan menghasilkan produk yang berkualitas, akan tercapai sebuah kegitan produksi yang efektif dan efisien. Karena produk yang dihasilkan sesuai dengan kebutuhan dan harapan pelanggan. Selain itu dengan diterapkannya quality control yang ketat perusahaan akan terhindar dari kegiatan yang tidak menghasilkan produk atau jasa yang tidak dibutuhkan oleh pelanggan.

Peningkatan pangsa pasar, pangsa pasar suatu organisasi akan tercapai bila minimalisasi biaya tercapai, karena organisasi, atau perusahaan dapat menekan harga, walaupun kualitas tetap menjadi yang utama.

Pertanggung jawaban produk, dengan semakin meningkatnya persaingan kualitas produk atau jasa yang dihasilkan, maka organisasi akan dituntut untuk semakin bertanggung jawab terhadap desain, proses, dan pendistribusian produk tersebut untuk memenuhi kebutuhan dan harapan pelanggan.

Dampak internasional, Bila suatu organisasi dapat menawarkan produk atau jasa yang bekualitas, maka selain dikenal dipasar lokal, produk atau jasa yang ditawarkan juag akan dikenal dan diterima di pasar internasional.

Penampilan produk atau jasa dan Mewujudkan Kualitas yang dirasakan, kualitas akan membuat suatu produk dikenal, dan hal ini akan membuat perusahaan atau organisasi yang menghasilkan produk atau menawarkan jasa yang juga dikenal dan dipercaya masyarakat luas.

\subsection{Minat Pembelian}

Minat pembelian bisa diperoleh dari suatu proses pembelajaran berupa pengalaman dan proses berpikir yang akhirnya membentuk suatu persepsi. Minat pembelian ini menciptakan suatu pengalaman baik dan pada akhirnya membentuk motivasi yang terekam dan pada akhirnya ketika seorang konsumen harus memenuhi kebutuhannya akan mewujudkan apa yang ada didalam benaknya itu. Minat beli merupakan kecendrungan konsumen untuk membeli suatu merek atau mengambil tindakan yang berhubungan dengan pembelian yang diukur dengan tingkat kemungkinan konsumen melakukan pembelian. Minat beli merupakan suatu yang berhubungan dengan rencana konsumen untuk membeli produk tertentu dalam waktu tertentu. Pembelian nyata terjadi apabila konsumen telah memiliki minat untuk membeli sebuah produk. Pembelian nyata merupakan sasaran akhir konsumen dimana minat beli merupakan pernyataan mental konsumen yang merefleksikan perencanaan untuk membeli sejumlah produk dengan merk tertentu, pengetahuan akan produk yang akan dibeli sangat diperlukan oleh konsumen

"Minat pembelian yang muncul menciptakan sebuah dorongan yang terekam dalam benaknya, yang pada akhirnya ketika seorang konsumen harus memenuhi kebutuhannya akan mengaktualisasikan apa yang ada didalam benaknya itu. Meskipun merupakan pembelian yang belum tentu akan dilakukan pada masa mendatang namun pengukuran terhadap minat pembelian 
JRNAL ПMПAH

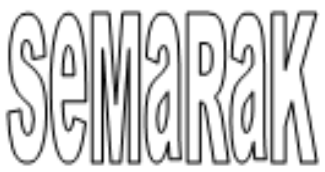

P-ISSN 2615-6849, E-ISSN 2622-3686

Jurnal Semarak,Vol.4,No.2,Juni 2021, Hal (32-37)

@ Prodi Manajemen Fakultas Ekonomi Universitas Pamulang

umumnya dilakukan guna memaksimumkan prediksi terhadap pembelian aktual itu sendiri”" (Kinnear dan Taylor, 1995).

Menurut Ferdinand (2006), "minat beli dapat diidentifikasikan melalui indikatorindikatorsebagai berikut : Minat transaksional, yaitu kecenderungan untuk membeli produk, Minat referensial, yaitu kecenderungan seseorang untuk mereferensikan produk kepada orang lain, Minat preferensial, yaitu minat yang menggambarkan perilaku seseorang yang memiliki preferensi utama pada produk tersebut. Preferensi ini hanya dapat diganti jika terjadi sesuatu dengan produk preferensinya", Minat eksploratif, minat ini menggambarkan perilaku seseorang yang selalu mencari informasi mengenai produk yang diminatinya dan mencari informasi untuk mendukung sifat-sifat positif dari produk tersebut.

\subsection{Penelitian Serupa}

Dalam penelitian sebelumnya yang berjudul "Analisis Pengaruh Kualitas Pelayanan, Kualitas Produk dan Promosi Penjualan terhadap Minat Beli (Studi pada Konsumen Buket Koffee dan Jazz)" oleh Freida Triastuti RJ (2012) menunjukkan adanya pengaruh positif variable Kualitas Pelayanan, Kualitas Produk dan Promosi Penjualan terhadap Minat Beli.

Dengan hasil penelitian bahwa bahwa kualitas produk memiliki pengaruh yang paling besar, kualitas produk semakin terjaga dan ditingkatkan maka akan terciptanya minat beli yang tinggi

H1: Kualitas produk berpengaruh positif terhadap minat pembelian oleh konsumen.

Harga dan Hubungan Harga dengan Minat Beli Konsumen Harga merupakan salah satu faktor yang dipertimbangkan konsumen dalam pengambilan keputusan pembelian. William J. Stanton (1998) memberikan definisi mengenai harga adalah sejumlah uang yang dibutuhkan untuk mendapatkan sejumlah kombinasi dari produk dan pelayanannya.

Pada penelitian sebelumnya yang berjudul "Analisis Pengaruh Citra Merek, Persepsi
Harga, dan Daya tarik Iklan terhadap Minat beli Konsumen pada Produk Air Minum Dalam Kemasan (AMDK) Galon Merek AQUA ( Studi Pada Mahasiswa di Kota Semarang)" oleh Kiki Norfiyanti (2012) menyatakan bahwa ada hubungan antara harga dengan minat beli konsumen. Kesesuain harga dengan produk yang didapat mempengaruhi minat beli konsumen, apabila harga yang dibayar sebanding dengan kualitas produk yang didapat maka minat beli konsumen akan meningkat. H2: Harga positif terhadap minat beli konsumen

\section{METODOLOGI PENELITIAN 3.1 Rancangan Penelitian}

Dalam penelitian ini terdiri dari beberapa variable yang biasa ada dalam penelitian, yaitu variable independen yang terdiri dari : harga (X1), kualitas produk (X2), selain itu terdapat pula variabel dependen yaitu minat beli (Y) pada pelanggan peyek Berkah Bersaudara.

Objek pada penelitian ini adalah para pelanggan atau outlet tempat produk peyek Berkah Bersaudara dipasarkan kepada pelanggan, metode penelitian ini menggunakan metode asosiatif pendekatan kuantitatif dengan jumlah sampel jenuh sebanyak 67 outlet.

Metode pengumpulan data yang digunakan ialah angket kuesioner. Analisis data yang digunakan yaitu analisis regresi linear berganda dan uji asumsi klasik

Menurut Kotler dan Amstrong (2008 : 278) ada 4 indikator yang mencirikan harga (X1), yaitu: keterjangkauan harga, kesesuaian harga dengan kualitas produk, daya saing harga, dan kesesuaian harga dengan manfaat. Lokasi adalah tempat dimana suatu usaha atau aktivitas usaha dilakukan.

Indikator untuk kualitas produk (X2) yaitu: 1. Performance (kinerja produk tersebut), sangat erat berhubungan dengan karakteristik dasar dari sebuah produk yang dijual. 2 . Durability (daya tahan produk tersebut), yang berarti berapa lama sebuah produk dapat bertahan sebelum produk tersebut rusak atau harus diganti.

Menurut Ferdinand (2006), minat beli (Y) dapat diidentifikasikan melalui indikator- 
indikator sebagai berikut : Minat transaksional, yaitu kecenderungan untuk membeli produk, Minat referensial, yaitu kecenderungan seseorang untuk memberikan referensi kepada orang lain, Minat preferensial, yaitu minat yang menggambarkan keinginan mengutamakan pembelian terhadap suatu produk tertentu.

Menurut Kinnear dan Taylor (1995), "minat beli adalah tahap kecenderungan responden untuk bertindak sebelum keputusan membeli benar- benar dilaksanakan". "Minat beli ulang merupakan suatu minat yang didasarkan atas pengalaman pembelian sebelumnya. minat beli ulang pada dasarnya adalah perilaku pelanggandimana pelanggan merespons positif terhadap kulitas pelayanan suatu perusahaandan berniat melakukan kunjungan kembali atau mengkonsumsi kembali produk perusahaan tersebut" (Cronin, dkk. 1992). Minat beli ulang tercipta karena konsumen merasa kualitas produk dan kualitas pelayanan yang diberikan sesuai apa yang mereka harapkan sehingga konsumen akan berniat untuk membeli produk kita di waktu selanjutnya.

"Minat beli yang muncul menciptakan suatu motivasi yang terus terekam dalam benaknya, yang pada akhirnya ketika seorang konsumen harus memenuhi kebutuhannya akan mengaktualisasikan apa yang ada didalam benaknya itu. Meskipun merupakan pembelian yang belum tentu akan dilakukan pada masa mendatang namun pengukuran terhadap minat pembelian umumnya dilakukan guna memaksimumkan prediksi terhadap pembelian aktual itu sendiri" (Kinnear dan Taylor, 1995)

Berdasarkan paparan diatas maka hipotesis yang diusulkan adalah sebagai berikut :

$\mathrm{H}_{1}=$ Diduga terdapat pengaruh positif dan pengaruh signifikan untuk variabel harga terhadap variable lainnya yaitu minat beli produk peyek kacang Berkah Bersaudara.

$\mathrm{H}_{2}=$ Diduga terdapat pengaruh yang positif dan signifikan variabel kualitas produk terhadap minat beli produk peyek kacang Berkah Bersaudara
$\mathrm{H}_{3}=$ Diduga terdapat pengaruh yang positif dan signifikan variabel harga dan kualitas produk terhadap minat beli produk peyek kacang Berkah Bersaudara.

\subsection{Tempat Penelitian}

Dalam penyusunan jurnall ini diperlukan data yang ada relevansinya dengan obyek yang akan diteliti. Dan untuk pengumpulan data tersebut maka penulis dalam hal ini mengadakan penelitian pada produsen peyek kacang Berkah Bersaudara yang berlokasi di Perumahan Bukit Sutera, Jalan Terusan Haji Nawi Malik, Blok A3-3A, dan penyebaran angket questioner dibantu oleh pemilik sekaligus tenaga penjual produk peyek Berkah Bersaudara yaitu Bapak Nanang.

Penyebaran angket atau kuesioner dilakukan kepada para outlet sebagai reseller atau agen dari proyek bersaudara yaitu para pemilik warung nasi warung tegal warung kelontong warung sembako tukang sayur warung Soto tempat kedai bakso dan sebagainya yang tersebar disekitaran Kecamatan Bojongsari Depok dan sekitar Ciputat dan Pamulang kota Tangerang Selatan.

\subsection{Waktu Pelaksanaan Penelitian}

Waktu pelaksanaan penelitian ini pada bulan Oktober 2020 s/d November 2020. Waktu 2 (dua) bulan ini dilaksanakan secara bertahap, hal pertama yang dilakukan adalah prasurvei (Pendahuluan), permohonan ijin kepada pemilik usaha peyek Berkah Bersaudara, Bapak Nanang, pengambilan data penelitian, pengolahan data, penyusunan laporan akhir.

Pengumpulan data merupakan upaya untuk mendapatkan informasi yang akan digunakan dalam pengukuran variabel. Menurut Sugiyono (2016) "Metode pengumpulan data adalah cara ilmiah utuk mendapatkan data yang valid dengan tujuan dapat dibuktikan, dikembangkan suatu pengetahuan sehingga dapat digunakan memecahkan dan mengantisipasi masalah". 
JRNAL ПMПAH

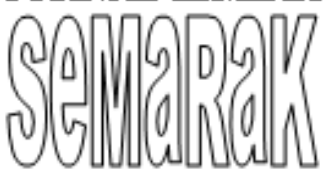

\subsection{Pengamatan (Observasi)}

Adapun pengertian observasi menurut pendapat Sugiyono (2016:141) menjelaskkan bahwa "Obeservasi adalah dasar semua ilmu pengetahuan. Dalam hal ini penulis melaksanakan pengamatan secara langsung terhadap produsen peyek Berkah Bersaudara dari mulai proses produksi sampai dengan pemasaran produk peyek Berkah Bersaudara tersebut dimana pengamatan yang dilakukan terbatas hanya pada pokok permasalahan dan meneliti secara langsung kepada objek penelitian dimana data yang akan diperoleh dapat digunakan untuk data tambahan dalam melakukan analisis.

Adapun pengertian kuesioner menurut pendapat Suharsimi Arikunto (2010:194) mengemukakan "Kuesioner adalah sejumlah pertanyaan tertulis yang digunakan untuk memperoleh informasi dari responden dalam arti laporan tentang pribadi atau hal-hal yang ia ketahui".

Adapun wawancara, menurut pendapat Sugiyono (2016:137) berpendapat bahwa "wawancara merupakan metode yang digunakan untuk memperoleh informasi secara langsung, mendalam, tidak terstruktur, dan individual".

Dalam penelitian ini untuk mendapatkan data primer penulis melakukan wawancara langsung dengan pihak terkait untuk mendapatkan informasi tentang bagaimana proses produksi dan proses pemasaran produk peyek Berkah Bersaudara.

Menurut Sugiyono (2016:140) berpendapat "Studi kepustakaan berkaitan dengan kajian teoritis dan referensi lain yang berkaitan dengan nilai, budaya dan norma yang berkembang pada situasi sosial yang diteliti, selain itu studi kepustakaan sangat penting dalam melakukan penelitian, hal ini dikarenakan penelitian tidak akan lepas dari literature-literatur ilmiah". Dalam hal ini peneliti mencari landasan teori yang berhubungan dengan judul penelitian guna memperoleh informasi tentang harga dan pengaruh harga, kualitas dan pengaruhnya kualitas produk terhadap munculnya minat beli produk peyek Berkah Bersaudara, dengan membaca buku, jurnal, karya tulis, dan literature yang relevan serta mencari hubungan yang sinkron antar variabel.

\subsection{Teknik Analisis Data}

Menurut pendapat Sugiyono (2016:147) "Analisis data merupakan kegiatan menganalisis setelah data dari seluruh responden terkumpul. Kegiatan dalam analisis data mengelompokkan data berdasarkan variabel, mentabulasi, menyajikan dari setiap variabel yang diteliti, melakukan perhitungan untuk menguji hipotesis yang telah diajukan". Kegiatan dalam menganalisis data adalah diantaranya membuat kelompok - kelompok data, mentabulasi data yang dikumpulkan, menyajikan data berdasarkan variable yang sudah diteliti, melakukan pengolahan data untuk menjawab perumusan masalah, dan melakukan olah data untuk menguji hipotesis hipotesis yang diajukan. Menurut pendapat dari Sugiyono (2016:148) "Skala pengukuran merupakan kesepakatan yang digunakan sebagai acuan untuk menentukan panjang pendeknya interval yang ada dalam alat ukur sehingga bila digunakan akan menghasilkan data kuantitatif".

Adapun untuk skala pengukuran yang akan digunakan dalam penelitian ini adalah skala likert. Dimana variable - variable yang akan diukur dideskripsikan dalam indikator variabel. Nilai dari berbagai variabel dengan instrumen yang menggunakan skala likert mempunyai gradasi diantaranya berikut ini :

Tabel 2. Skala Likert

\begin{tabular}{|l|l|l|l|}
\hline No. & Jawaban & Kode & Skor \\
\hline 1. & Sangat Setuju & SS & 5 \\
\hline 2. & Setuju & S & 4 \\
\hline 3. & Kurang setuju & KS & 3 \\
\hline 4. & Tidak Setuju & TS & 2 \\
\hline 5. & Sangat Tidak Setuju & STS & 1 \\
\hline
\end{tabular}

Untuk menentukan nilai dan rentang skala dari setiap variabel dan indicator yang diukur dapat ditetapkan range interval untuk menggambarkan penafsiran atau interprestasi : 
Tabel 3. Kriteria Rentang Suara

\begin{tabular}{|l|l|l|l|}
\hline No & Skor & Interval & Jawaban \\
\hline 1 & 5 & $\begin{array}{l}4,20- \\
5,00\end{array}$ & $\begin{array}{l}\text { Sangat Setuju } \\
\text { (SS) }\end{array}$ \\
\hline 2 & 4 & $\begin{array}{l}3,40- \\
4,19\end{array}$ & Setuju (S) \\
\hline 3 & 3 & $\begin{array}{l}2,60- \\
3,39\end{array}$ & $\begin{array}{l}\text { Kurang Setuju } \\
\text { (KS) }\end{array}$ \\
\hline 4 & 2 & $\begin{array}{l}1,80- \\
2,59\end{array}$ & $\begin{array}{l}\text { Tidak Setuju } \\
\text { (TS) }\end{array}$ \\
\hline 5 & 1 & $\begin{array}{l}1,00- \\
1,79\end{array}$ & $\begin{array}{l}\text { Sangat Tidak } \\
\text { Setuju (STS) }\end{array}$ \\
\hline
\end{tabular}

\section{INDIKATOR}

Indikator harga (X1), yaitu:

1. Keterjangkauan harga,

2. Kesesuaian harga dengan kualitas produk,

3. Daya saing harga,

4. Kesesuaian harga dengan manfaat.

Indikator kualitas produk (X2) yaitu:

1. Performance (kinerja) dalam hal ini karena berupa makanan produk peyek Berkah Bersaudara maka kinerja diartikan dengan rasa,

2. Durability (daya tahan) dalam hal ini karena berupa makanan produk peyek Berkah Bersaudara maka kinerja diartikan dengan jumlah produk dalam satu kemasan.

Indikator Minat beli (Y)

1. Minat transaksional

2. Minat referensial

3. Minat preferensial

\section{ANALISA \& PEMBAHASAN}

\subsection{Deskripsi Responden}

Deskripsi atau penjelasan responden yang ada dalam penelitian ini terdiri dari berbagai macam, diantaranya usia responden, jenjang pendidikan responden dan jabatan responden, untuk Jumlah responden penelitian ini sebanyak 67 orang yang ikut berpartisipasi dalam pengisian instrumen kuesioner. Berikut ini adalah hasil frekuensi deskripsi responden:

a. Frekuensi Usia Responden

Output usia responden adalah sebagai berikut :

Kelompok responden berdasarkan usia

Tabel 4. Kelompok responden berdasarkan usia, Sumber : data olahan kuesioner 2020

\begin{tabular}{|l|l|l|l|}
\hline No. & $\begin{array}{c}\text { Rentang } \\
\text { Usia }\end{array}$ & Jumlah & \multicolumn{1}{|c|}{$\begin{array}{c}\text { Persentase } \\
(\%)\end{array}$} \\
\hline 1. & $20-30$ & 37 & $55,22 \%$ \\
\hline 2. & $31-40$ & 21 & $31,35 \%$ \\
\hline 3. & $41-58$ & 9 & $13,43 \%$ \\
\hline & Jumlah & 67 & $100 \%$ \\
\hline
\end{tabular}

Dari hasil data diatas dapat digambarkan bahwa responden mayoritas dalam penelitian ini adalah yang berusia 20 tahun sampai 30 tahun berjumlah $55,22 \%$, yang berusia 31 tahun sampai 40 tahun berjumlah $31,35 \%$, dan yang berusia 41 tahun sampai 58 tahun berjumlah $13,43 \%$.

b. Status Responden

Kelompok responden berdasarkan kategori status outlet responden.

\begin{tabular}{|l|l|c|c|}
\hline No. & \multicolumn{1}{|c|}{ Outlet } & Jumlah & $\begin{array}{c}\text { Presentase } \\
(\%)\end{array}$ \\
\hline 1. & $\begin{array}{l}\text { Mie Ayam } \\
\text { Gerobak }\end{array}$ & 2 & $2,98 \%$ \\
\hline 2. & $\begin{array}{l}\text { Warung } \\
\text { Soto }\end{array}$ & 3 & $4,47 \%$ \\
\hline 3. & $\begin{array}{l}\text { Tukang } \\
\text { Sayur } \\
\text { Mangkal }\end{array}$ & 12 & $17,92 \%$ \\
\hline 4. & $\begin{array}{l}\text { Tukang } \\
\text { Sayur } \\
\text { Keliling }\end{array}$ & 12 & $17,92 \%$ \\
\hline 5. & $\begin{array}{l}\text { Warung } \\
\text { Sembako }\end{array}$ & 38 & $56,71 \%$ \\
\hline & Jumlah & 67 & $100 \%$ \\
\hline
\end{tabular}


JRNAL ПММАH

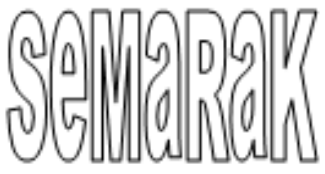

Tabel 5. Kelompok responden berdasarkan jenisnya Sumber : data olahan kuesioner 2020

\subsection{Analisa deskriptif}

Analisa deskriptif adalah analisa statistik yang digunakan untuk menganalisa data dengan cara mendeskripsikan data yang ada dengan apa adanya tanpa bermaksud untuk memberikan kesimpulan yang berlaku secara umum atau generalisasi data. Untuk mengetahui bagaimana menggunakan rentang skala dan rata - rata dalam analisa deskriptif, skor instrument diterjemahkan ke dalam sebuah table.

\section{a. Analisis Hasil Kuesioner}

Peneliti melakukan analisis kuantitatif berdasarkan data hasil kuesioner yag telah diberikan kepada 67 responden. Responden dalam penelitian ini adalah para pemilik atau pegawai atau orang yang ditemukan sedang menjaga outlet tempat dimana produk yang sedang diteliti, peyek kacang Berkah Bersaudara dipasarkan, sebagai pengukur yang akan dijelaskan sebagai berikut.

1) Variabel $X_{1}$ (Harga)

Tabel 6

Hasil data kuesioner harga $\left(\mathrm{X}_{1}\right)$

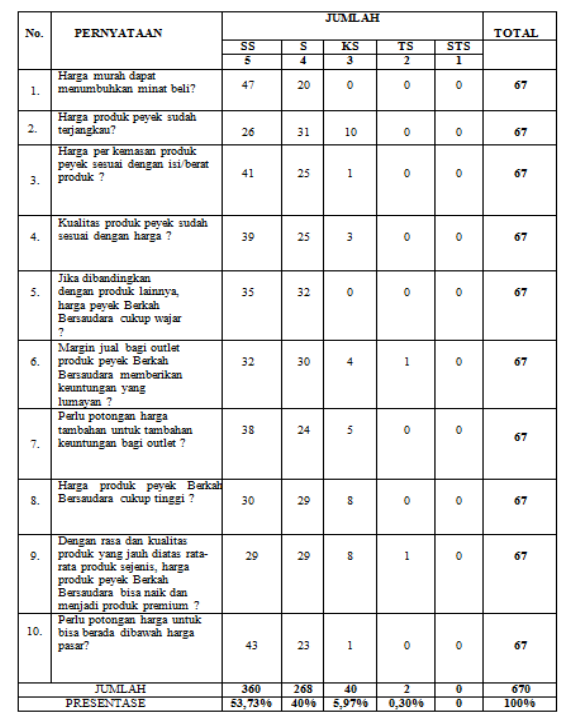

Sumber : data olahan kuesioner 2020

Dari semuanya responden sebanyak 67 responden yang mana terdapat 10 pernyataan yang memilih untuk menjawab "SANGAT SETUJU" adalah paling besar jumlahnya, yaitu sebesar 53,73\%, maka kesimpulannya adalah $53,73 \%$ responden menilai sangat setuju tentang harga.

\section{2) Variabel $X_{2}$ (Kualitas Produk)}

Tabel 7

Hasil data kuesioner Kualitas Produk $\left(\mathbf{X}_{2}\right)$

\begin{tabular}{|c|c|c|c|c|c|c|c|}
\hline \multirow{3}{*}{ No. } & \multirow{3}{*}{ PERNYATAAN } & \multicolumn{5}{|c|}{ JUMLAH } & \multirow{3}{*}{ TOTAI } \\
\hline & & SS & $\mathrm{s}$ & KS & TS & STS & \\
\hline & & 5 & 4 & 3 & 2 & 1 & \\
\hline 1. & $\begin{array}{l}\text { Kalan makan di wanung nasi } \\
\text { saya pasti mancari payek } \\
\text { kacang sobagai kriuk dan } \\
\text { penambah selera makan }\end{array}$ & 42 & 25 & 0 & 0 & 0 & 67 \\
\hline 2. & $\begin{array}{l}\text { Ibu - ibu selalu membeli kriuk } \\
\text { selain krupuk di tukang sayur, } \\
\text { payek kacang tentunya }\end{array}$ & 38 & 29 & 0 & 0 & 0 & 67 \\
\hline 3. & $\begin{array}{l}\text { Makan mie ayam, soto ayam, } \\
\text { soto betaxui dan anaka } \\
\text { panganan berkuah lainnya } \\
\text { tidak enak kalau tidak dengan } \\
\text { payek kacang }\end{array}$ & 39 & 26 & 2 & 0 & 0 & 67 \\
\hline 4. & $\begin{array}{l}\text { Kalsu enak, pasti saya } \\
\text { merefenensikannya kapsia } \\
\text { orang lain, dan produk payek } \\
\text { kacang Berkah Bersandara } \\
\text { enak gekali }\end{array}$ & 50 & 17 & 0 & 0 & 0 & 67 \\
\hline 5. & $\begin{array}{l}\text { WVarung gembakoo } \\
\text { menyediakan payek kacang } \\
\text { Berkah Bersaudara karena } \\
\text { banyak yang cari }\end{array}$ & 30 & 36 & 1 & 0 & 0 & 67 \\
\hline 6. & $\begin{array}{l}\text { Warung Mie ayam terkadang } \\
\text { menyediakan pangsit goreng } \\
\text { sahingga banyak warumg mie } \\
\text { ayam yang kurang cocok } \\
\text { dengan produk peyyk kacang }\end{array}$ & 50 & 17 & 0 & 0 & 0 & 67 \\
\hline 7. & $\begin{array}{l}\text { Berbada dengan warnumg mie } \\
\text { ayam, warung nasi, bubur } \\
\text { ayam dan warumg anaka soto } \\
\text { genang mamajang produk } \\
\text { peyel karana bisa menambah } \\
\text { keuntungan }\end{array}$ & 40 & 22 & 5 & 0 & 0 & 67 \\
\hline 8. & 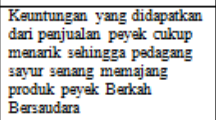 & 40 & 27 & 0 & 0 & 0 & 67 \\
\hline 9. & $\begin{array}{l}\text { Penginiman produl yang } \\
\text { teratur turut manjaga kualitas } \\
\text { sehingga para pemilik outlat } \\
\text { tidak khawatir dengan produk }\end{array}$ & 37 & 30 & 0 & 0 & 0 & 67 \\
\hline 10. & $\begin{array}{l}\text { Harga yang terjangkan turut } \\
\text { mempemmudah para penilik } \\
\text { outlet mendorong minat beli } \\
\text { konsumen }\end{array}$ & 49 & 18 & 0 & 0 & 0 & 67 \\
\hline & JUMILAH & 415 & 247 & 8 & 0 & 0 & 670 \\
\hline & PRESENTASE & 61,9496 & $\begin{array}{c}36,87 \\
9 \%\end{array}$ & $1,190 \%$ & 0 & 0 & $\begin{array}{c}100 \\
9 \%\end{array}$ \\
\hline
\end{tabular}

Dapat disimpulkan bahwa dari semuanya responden sebanyak 67 responden, terdapat 10 pernyataan yang memilih untuk menjawab untuk menjawab "SANGAT SETUJU" adalah yang paling besar jumlahnya yaitu sebesar $52,84 \%$, yang mana artinya responden $52,84 \%$ 
JRNAL ПMПAH

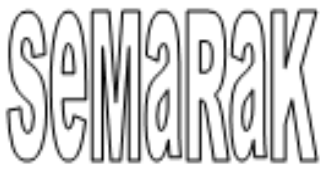

P-ISSN 2615-6849, E-ISSN 2622-3686

Jurnal Semarak,Vol.4,No.2,Juni 2021, Hal (32-37)

@ Prodi Manajemen Fakultas Ekonomi Universitas Pamulang

ini menilai sangat setuju dengan kualitas produk.

3) Variabel Y (Minat Beli)

Tabel 8

Hasil data kuesioner minat beli (Y)

\begin{tabular}{|c|c|c|c|c|c|c|c|}
\hline \multirow{3}{*}{ No. } & \multirow{3}{*}{ PERNYATAAN } & \multicolumn{5}{|c|}{ JUMAAH } & \multirow{3}{*}{ TOTAL } \\
\hline & & SS & $\mathrm{s}$ & $\mathrm{KS}$ & TS & STS & \\
\hline & & 5 & 4 & 3 & 2 & 1 & \\
\hline 1. & $\begin{array}{l}\text { Bantuk produk payek tidak } \\
\text { banyak yang hancur }\end{array}$ & 39 & 27 & 1 & 0 & 0 & 67 \\
\hline 2. & \begin{tabular}{|l} 
TVama produk payek alami \\
tampa pewama bustan
\end{tabular} & 34 & 24 & 8 & 0 & 1 & 67 \\
\hline 3. & \begin{tabular}{|l|} 
Produk peyek tahan lama, \\
setidaknya 7 - 9 hari tetap \\
dengan rasa dan kerenyahan \\
yang sama
\end{tabular} & 40 & 25 & 1 & 1 & 0 & 67 \\
\hline 4. & $\begin{array}{l}\text { Bentuk kemasan terlihat } \\
\text { culup baik }\end{array}$ & 35 & 29 & 3 & 0 & 0 & 67 \\
\hline 5. & $\begin{array}{l}\text { Tampilan kemasan produk } \\
\text { menunjukkan kesan cukup } \\
\text { baik }\end{array}$ & 26 & 21 & 12 & 6 & 2 & 67 \\
\hline 6. & $\begin{array}{l}\text { Wakttu rotasi panggantian } \\
\text { produk peyek di outlet sudah } \\
\text { cukup baik dalam manjaga } \\
\text { kualitas produk }\end{array}$ & 41 & 26 & 0 & 0 & 0 & 67 \\
\hline 7. & \begin{tabular}{|l|} 
Secara umum kemasan \\
produk cukup menjaga \\
kualitas produk agar rasa \\
dan kerenyahan tetap terjaga
\end{tabular} & 45 & 20 & 2 & 0 & 0 & 67 \\
\hline 8. & $\begin{array}{l}\text { Secara umum tampilan } \\
\text { kemazan culupp menarik } \\
\text { minat pembeli }\end{array}$ & 32 & 35 & 0 & 0 & 0 & 67 \\
\hline 9. & $\begin{array}{l}\text { Karenyahan dan rasa produk } \\
\text { peyek cukup tajaga dengan } \\
\text { baik }\end{array}$ & 32 & 31 & 2 & 2 & 0 & 67 \\
\hline 10. & \begin{tabular}{|l|} 
Salah satu ciri produk peyek \\
berkualitas sdalah tidak \\
banyak yang hancur karena \\
proses pangiriman
\end{tabular} & 30 & 33 & 3 & 1 & 0 & 67 \\
\hline & JUMLAH & 354 & 271 & 32 & 10 & 3 & 670 \\
\hline & RESENTASE & 52,8496 & 40,4496 & $4,789 \%$ & $1,5 \%$ & 0,4496 & $\begin{array}{l}100 \\
96\end{array}$ \\
\hline
\end{tabular}

Dengan responden yang berjumlah 67 responden, terdapat 10 pernyataan yang mana responden memilih menjawab "SANGAT SETUJU" adalah paling besar nilainya yaitu sebesar $61,94 \%$ ini artinya responden menilai sangat setuju dengan minat beli

\subsection{Uji Asumsi Klasik}

Uji asumsi klasik biasanya dilakukan untuk mencari, seberapa jauh ketepatan dari data yang ada. Menurut pendapat Singgih Santoso (2011:342) menjelaskan "Sebuah model regresi akan digunakan untuk melakukan peramalan sebuah model yang baik adalah model dengan kesalahan peramalan yang seminimal mungkin. Karena itu, sebuah model sebelum digunakan seharusnya memenuhi beberapa asumsi, yang biasa disebut asumsi klasik". Pada penelitian ini, uji asumsi klasik yang dilakukan adalah diantaranya Uji Normalitas, Uji Multikolinearitas, Uji Heterokedastisitas.

1) Uji Normalitas

Uji normalitas dilakukan untuk menguji dalam sebuah model yang disebut regresi, variabel - variabel yang ada, yaitu variabel dependen dan variabel independen, atau keduanya mempunyai distribusi yang normal atau tidak. Menurut pendapat Ghozali (2013:160) "model regresi yang baik adalah berdistribusi normal atau mendekati normal".

Tabel 4.17 Hasil Uji Normalitas

\begin{tabular}{|c|c|c|}
\hline \multicolumn{3}{|c|}{ One-Sample Kolmogorov-Smirnov Test } \\
\hline & & Unstandardized Predicted Value \\
\hline $\mathrm{N}$ & & 67 \\
\hline \multirow{2}{*}{$\begin{array}{l}\text { Normal } \\
\text { Parameters }{ }^{\mathrm{a}, \mathrm{b}}\end{array}$} & Mean & 46,0746269 \\
\hline & $\begin{array}{l}\text { Std. } \\
\text { Deviation }\end{array}$ & 1,62633048 \\
\hline \multirow{3}{*}{$\begin{array}{l}\text { Most } \\
\text { Extreme } \\
\text { Differences }\end{array}$} & Absolute & 132 \\
\hline & Positive &, 079 \\
\hline & Negative &,- 132 \\
\hline \multicolumn{2}{|c|}{ Kolmogorov-Smirnov Z } & 1,080 \\
\hline \multicolumn{2}{|c|}{ Asymp. Sig. (2-tailed) } &, 194 \\
\hline
\end{tabular}

a. Test distribution is Normal.

b. Calculated from data.

Sumber : Data olahan kuesioner SPSS Versi 2.0

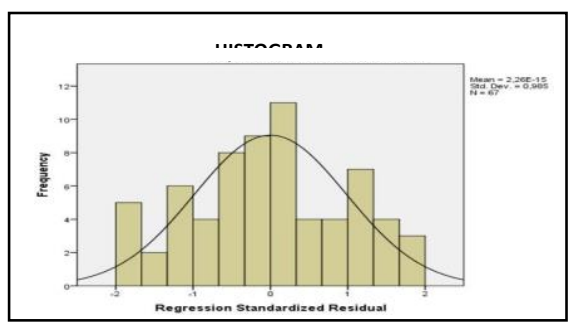

Gambar 4.2 Histogram

Sumber : Data olahan kuesioner SPSS Versi 2.0 


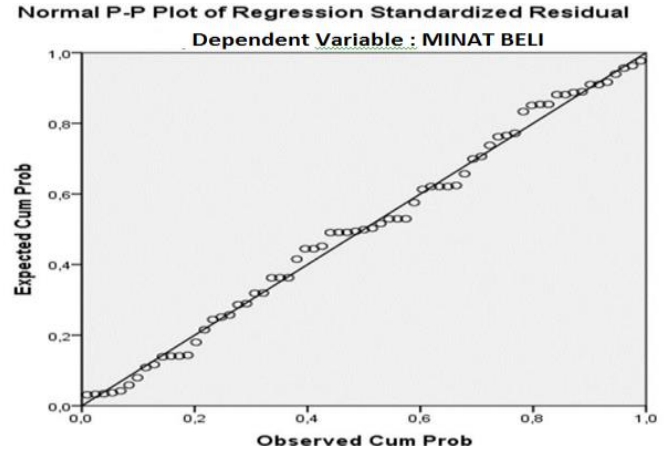

Gambar 4.3 Normal plot

Sumber : Data olahan kuesioner SPSS Versi 2.0

Berdasarkan uji normalitas dengan kologorov-smirnov test diperoleh nilai asymp.sig sebesar 0,194 lebih besar dari 0,05 maka dapat disimpulkan data berdistribusi normal. Untuk mengetahui kriterianya dibandingkan dengan distribusi kumulatif dari distribusi normal.

Menurut pendapat Ghozali (2013:164) "dasar dalam pengambilan sebuah keputusan adalah sebagai berikut" :

1) "Jika data yang didapat menyebar disekitar garis diagonal dan tren data tersebut mengikuti arah garis diagonal, maka dapat disimpulkan model regresi memenuhi normalitas."

2) "Jika data terlihat menyebar dan menjauh dari garis diagonal atau tidak dalam posisi tren mengikuti arah garis diagonal, maka dapat disimpulkan model regresi tidak memenuhi normalitas."

Hal ini dapat dilihat pada gambar di atas bahwa data menyebar disekitar garis diagonal (tidak berjarak terlalu jauh dari garis diagonalnya) dan mengikuti arah garis diagonalnya, maka model regresi memenuhi normalitas.

Dengan demikian dapat disimpulkan bahwa pengujian pada model regresi ini berdistribusi normal dan bisa dilanjutkan pada pengujian berikutnya.

2) Uji Multikolinearitas
Menurut pendapat Ghozali, (2013:105) memberikan pendapat bahwa "Uji multikolinearitas bertujuan untuk menguji apakah pada model regresi ditemukan adanya korelasi antar variabel bebas (independen)".

Model regresi yang dinyatakan baik itu bila tidak ada multikolonearitas. Untuk dapat mengetahui hal itu, maka pedomannya adalah : a) Nilai tolerance

(1) Jika nilai tolerance lebih besar dari 0,1 maka tidak terjadi multikolinieritas.

(2) Jika nilai tolerance lebih kecil atau sama dengan 0,1 maka terjadi multikolinieritas.

\section{) Nilai VIF}

(1) Nilai VIF lebih kecil 10 maka tidak terjadi multikolinieritas.

(2) Nilai VIF lebih besar atau sama dengan 10 maka terjadi multikolinieritas.

Uji multikolinearitas dalam penelitian ini dilakukan dengan menggunakan alat bantu, untuk mengukurnya menggunakan IBM SPSS Statistics 2.0 for Windows.

Adapun ringkasan hasil uji multikolinearitas ada dalam tabel berikut.

Tabel 4.18

Hasil Uji Multikoleniaritas

\section{Coefficients $^{\mathrm{a}}$}

\begin{tabular}{|c|c|c|c|c|c|c|c|}
\hline \multirow[b]{2}{*}{ Model } & \multicolumn{2}{|c|}{$\begin{array}{c}\text { Unstandardized } \\
\text { Coefficients }\end{array}$} & \multirow{2}{*}{$\begin{array}{c}\text { Standardized } \\
\text { Coefficients }\end{array}$} & \multirow[b]{2}{*}{$t$} & \multirow[b]{2}{*}{ Sig. } & \multicolumn{2}{|c|}{$\begin{array}{l}\text { Collinearity } \\
\text { Statisticics }\end{array}$} \\
\hline & B & $\begin{array}{l}\text { Std. } \\
\text { Error }\end{array}$ & & & & Tolerance & $\mathrm{VIF}$ \\
\hline \begin{tabular}{|l|l|}
1 (Constant) \\
\end{tabular} & 23,278 & 3,975 & & 5,856 & 000 & & \\
\hline HARGA &, 243 & , 180 &, 344 & 3,027 & 004 &, 797 & 1,254 \\
\hline $\begin{array}{l}\text { KUALITAS } \\
\text { PRODUK }\end{array}$ & 268 &, 089 &, 343 & 3,019 &, 004 &, 797 & 1,254 \\
\hline
\end{tabular}

Sumber : Data primer olahan SPSS Versi 2.0

Dari tabel 4.18 diatas didapat Nilai VIF 1,254 dan tolerance 0,797. Data diatas 
menunjukkan bahwa Nilai VIF kurang dari 10 dan Nilai Tolerance lebih besar dari 0,1. Dengan demikian keadaan seperti ini membuktikan bahwa tidak terjadinya multikolinieritas.

Dari hasil data diatas disimpulkan bahwa data yang ada tidak terjadi gejala multikolonieritas antara masing-masing variabel independen, yaitu dengan melihat nilai VIF dan tolerance.

3) Uji heteroskedastisitas

Uji heteroskedasitas bertujuan untuk mengetahui apakah dalam model regresi terjadi ketidaksamaan varian dari suatu residual pengematan ke pangamatan yang lain.

"Jika titik-titik data yang diolah menyebar diatas dan juga dibawah angka 0 (nol) pada sumbu Y dengan tidak membentuk pola khusus maka dapat disimpulkan tidak terjadi heteroskedastisitas" (Ghozali :2013).

Untuk menganalisa asumsi Heteroskedastisitas bisa dengan cara melihat grafik scatter plot dimana :

a. Jika penyebaran data yang diolah pada scatter plot terlihat secara teratur dan membentuk pola khusus (seperti naik atau turun, mengelompok menjadi satu) maka dapat disimpulkan adanya masalah Heteroskedastisitas.

Jika penyebaran data yang diolah pada scatter plot terlihat tidak teratur dan tidak membentuk pola khusus (contohnya naik atau turun, mengelompok mejadi satu) maka dapat disimpulkan tidak terjadi masalah Heteroskedastisitas.

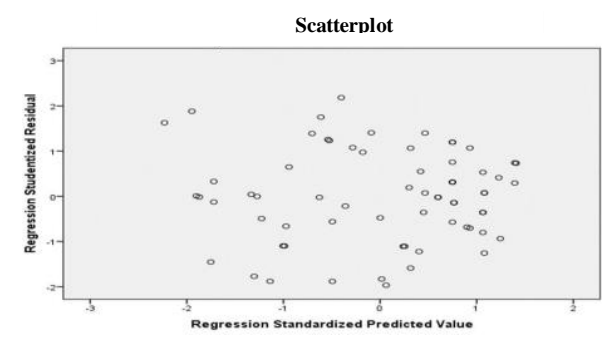

Sumber : Data primer olahan SPSS Versi 2.0

\section{Gambar 4.4 Grafik uji heteroskedastisitas}

Berdasarkan output grafik scatter plot pada gambar 4.4 diatas dapat dilihat bahwa titik-titik tersebar dengan baik dan tidak membentuk pola tertentu yang jelas, sehingga dapat disimpulkan bahwa tidak terjadi problem heteroskedastisitas.

\subsection{Uji Analisis}

1) Analisis Regresi Linier Berganda

Menurut Sugiyono (2016:277)

"analisis regresi digunakan untuk melakukan prediksi Bagaimana perubahan nilai variabel dependen bila nilai variabel independen dinaikan atau diturunkan".

\section{Tabel \\ 4.19}

\section{Hasil Uji Regresi Linear Berganda}

\section{Coefficients $^{\mathbf{a}}$}



Sumber : Data primer olahan SPSS Versi 2.0

Persamaan garis regresi yang dihasilkan berdasarkan keluaran tabel 4.19 ini ditentukan berdasarkan nilanilai aplikasi software program Statistical Package for Social Science (SPSS) for window versi 2.0. Maka didapat hasil persamaan regresi sebagai berikut : 


$$
Y=23,278+0,243 X_{1}+0,268 X_{2}
$$

Interpretasi dari persamaan regresi linear berganda di atas adalah

a. $\quad b=23,278$ artinya jika tidak terjadi perubahan variabel harga dan kualitas produk (nilai $\mathrm{X}_{1}$ dan $\mathrm{X}_{2}$ adalah 0) maka minat beli produk peyek kacang Berkah Bersaudara sebesar 23,278.

b. $b_{1}=0,243$ artinya jika variabel harga $\left(\mathrm{X}_{1}\right)$ meningkat sebesar $1 \%$ dengan asumsi variabel kualitas produk $\left(\mathrm{X}_{2}\right)$ dan konstanta (a) 0 (nol), maka minat beli produk peyek kacang Berkah Bersaudara meningkat sebesar 0,243. Hal tersebut menunjukkan bahwa variabel harga berkontribusi positif bagi minat beli, sehingga semakin tinggi harga maka semakin tinggi pula minat beli produk peyek kacang Berkah Bersaudara.

c. $b_{2}=0,268$ artinya jika variabel kualitas produk $\left(\mathrm{X}_{2}\right)$ meningkat sebesar $1 \%$ dengan asumsi variabel harga $\left(\mathrm{X}_{1}\right)$ dan konstanta (a) 0 (nol), maka kualitas produk produk peyek kacang Berkah Bersaudara pada meningkat sebesar 0,268. Hal tersebut menunjukkan bahwa kualitas produk berkontribusi positif bagi minat beli produk peyek kacang Berkah Bersaudara, sehingga semakin tinggi kualitas produk maka semakin tinggi minat beli produk peyek kacang Berkah Bersaudara.

2) Analisis Koefisien Korelasi

Tabel

4.20

Hasil Uji Analisis Regresi Koefisien Korelasi

\begin{tabular}{|c|c|c|c|c|}
\hline \multicolumn{5}{|c|}{ Correlations } \\
\hline & & MOTIVASI & $\begin{array}{l}\text { LINGKUNGAN } \\
\text { KERJA }\end{array}$ & KINERJA \\
\hline \multirow[t]{3}{*}{ HARGA } & $\begin{array}{l}\text { Pearson } \\
\text { Correlation }\end{array}$ & 1 & $450^{* *}$ & $498^{* *}$ \\
\hline & Sig. (2-tailed) & & 000 &, 000 \\
\hline & $\mathrm{N}$ & 67 & 67 & 67 \\
\hline \multirow[t]{3}{*}{$\begin{array}{l}\text { KUALITAS } \\
\text { PRODUK }\end{array}$} & \begin{tabular}{|l|} 
Pearson \\
Correlation
\end{tabular} & $450^{* *}$ & 1 & $498^{* *}$ \\
\hline & Sig. (2-tailed) &, 000 & &, 000 \\
\hline & $\mathrm{N}$ & 67 & 67 & 67 \\
\hline \multirow[t]{3}{*}{ MINAT BELI } & \begin{tabular}{|l|} 
Pearson \\
Correlation
\end{tabular} & $498^{* *}$ & $498^{* *}$ & 1 \\
\hline & Sig. (2-tailed) &, 000 &, 000 & \\
\hline & $\mathrm{N}$ & 67 & 67 & 67 \\
\hline
\end{tabular}

Sumber : Data primer olahan SPSS Versi 2.0

Dari hasil koefisien korelasi dari 67 kuesioner dihasilkan pengaruh harga sebesr 0,498 dan kualitas produk sebesar 0,498 dari r tabel sebesar 0,240. Dikatakan valid apabila $r$ hitung > dari $\mathrm{r}$ tabel. Maka harga 0,498 > 0,240, kualitas produk 0,498 >0,240. Maka dapat disimpulkan bahwa harga $\left(\mathrm{X}_{1}\right)$ dan kualitas produk $\left(\mathrm{X}_{2}\right)$ berpengaruh terhadap minat beli (Y).

\subsection{Uji Hipotesis \\ 1) Uji Hipotesis Uji t}

a) Pengujian Hipotesis $\mathrm{X}_{1}-\mathrm{Y}$

Langkah-langkah uji signifikansi koefisien regresi atau disebut uji t sebagai berikut:

(1) Hipotesis

Jika ternyata $\mathrm{t}$ hitung $>\mathrm{t}$ tabel sig. 0,05 maka dengan demikian $\mathrm{H} 0$ ditolak dan $\mathrm{H} 1$ diterima maka dikatakan $\mathrm{X}_{1}$ berpengaruh terhadap Y.

(2) Kriteria pengujian

$\mathrm{H} 0$ diterima jika $\mathrm{t}$ hitung $<\mathrm{t}$ tabel atau sig. $>0,05, \mathrm{H} 0$ ditolak jika $\mathrm{t}$ hitung $>\mathrm{t}$ tabel atau Sig. $<0,05, \mathrm{t}$ tabel $=\mathrm{t}(\mathrm{a} / 2 ; \mathrm{n}-\mathrm{k}-1) \mathrm{t}=$ $(0,025$

;64) $=1,997$.

(3) Perhitungan

Berdasarkan analisis menggunakan alat bantu aplikasi software program 
JRNAL ПММАH

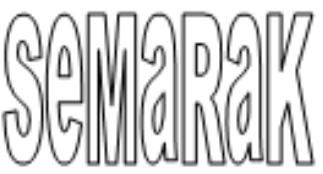

P-ISSN 2615-6849, E-ISSN 2622-3686

Jurnal Semarak,Vol.4,No.2,Juni 2021, Hal (32-37)

@ Prodi Manajemen Fakultas Ekonomi Universitas Pamulang

Statistical Package for Social Science (SPSS) for window versi 2.0. diperoleh $\mathrm{t}$ hitung sebesar 3,027 dengan signifikansi sebesar 0,004.

(4) Keputusan Uji

H0 ditolak dan $\mathrm{H} 1$ diterima karena nilai t hitung sebesar 3,027 > t tabel 1,997 dan nilai Sig. 0,004<0,05. Maka dapat disimpulkan bahwa harga $\left(\mathrm{X}_{1}\right)$ berpengaruh signifikan terhadap minat beli (Y).

b) Pengujian Hipotesis $\mathrm{X}_{2}-\mathrm{Y}$

Bunyi hipotesis kedua yang diajukan adalah "kualitas produk" $\left(\mathrm{X}_{2}\right)$ terhadap minat beli (Y)". Berdasarkan analisis regresi linear berganda diketahui bahwa koefisien regresi dari variabel $\mathrm{X}_{2}\left(\mathrm{~b}_{2}\right)$ adalah sebesar 0,268 atau bernilai positif, sehingga dapat dikatakan $\mathrm{X}_{2}$ berpengaruh positif terhadap Y. Untuk mengetahui pengaruh tersebut signifikan atau tidak, selanjutnya nilai koefisien regresi linear berganda dari $b_{2}$ diuji kadar signifikansinya. Pengujian signifikansi koefisien regresi atau uji t adalah :

(1) Hipotesis

Jika ternyata $\mathrm{t}$ hitung $>\mathrm{t}$ tabel sig. 0,05 maka $\mathrm{H} 0$ ditolak dan $\mathrm{H} 1$ diterima maka dikatakan $\mathrm{X}_{2}$ berpengaruh terhadap $\mathrm{Y}$.

(2) Kriteria pengujian

$\mathrm{H}_{0}$ diterima jika $\mathrm{t}$ hitung $<\mathrm{t}$ tabel atau sig. $>0,05, \mathrm{H}_{0}$ ditolak jika $\mathrm{t}$ hitung $>\mathrm{t}$ tabel atau Sig. $<0,05$, $\mathrm{t}$ tabel $=\mathrm{t}(\mathrm{a} / 2 ; \mathrm{n}-\mathrm{k}-1) \mathrm{t}=(0,025$ ; 64) $=1,997$.

(3) Perhitungan

Berdasarkan analisis menggunakan alat bantu aplikasi software program Statistical Package for Social Science (SPSS) for window versi 2.0. diperoleh $\mathrm{t}$ hitung sebesar 3,019 dengan signifikansi sebesar 0,004.

(4) Keputusan Uji

H0 ditolak dan H1 diterima karena nilai t hitung sebesar 3,019>t tabel 1,997 dan nilai Sig. 0,004<0,05. Maka dapat disimpulkan bahwa kualitas produk $\left(\mathrm{X}_{2}\right)$ berpengaruh signifikan terhadap minat beli (Y).

\section{PENUTUP}

\subsection{Kesimpulan}

Berdasarkan hasil penelitian, dapat disimpulkan sebagai berikut :

1. Hasil dari uji regresi berganda menunjukan kualitas produk memiliki koefisien regresi paling besar terhadap minat beli diantara variabel lainnya yang diteliti yaitu sebesar 0,268 . Kemudian variabel harga sebesar 0,243 .

2. Hipotesis pertama yang menyatakan bahwa Harga berpengaruh positif kepada minat beli produk peyek Berkah Bersaudara terbukti kebenarannya. Hal ini berarti bahwa harga merupakan salah satu faktor yang dapat mendorong konsumen untuk dapat menumbuhkan minat beli produk peyek Berkah Bersaudara.

3. Hipotesis kedua yang memberikan pernyataan bahwa Kualitas produk peyek Berkah Bersaudara berpengaruh secara positif terhadap minat beli produk peyek Berkah Bersaudara dapat dibuktikan. Hal ini memberikan bukti bahwa kualitas produk merupakan salah satu faktor yang terbukti dapat menumbuhkan minat beli

\subsection{Saran}

Sejalan dengan hasil penelitian maka diharapkan:

1) Variabel harga memiliki pengaruh yang positif terhadap minat beli, diharapkan produsen peyek Berkah Bersaudara dapat tetap dengan harga yang kompetitif karena pengaruh positif tersebut harus tetap dipertahankan semampunya untuk menjaga omset dan kelangsungan bisnis yang telah berjalan

2) Variabel kualitas produk memiliki pengaruh yang sama terhadap minat beli produk peyek Berkah Bersaudara, diharapkan produsen peyek Berkah Bersaudara dapat tetap menjaga 
JRNAL IMПAH

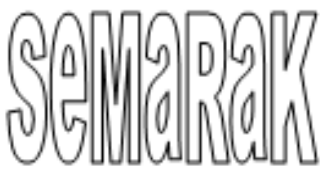

P-ISSN 2615-6849, E-ISSN 2622-3686

Jurnal Semarak,Vol.4,No.2,Juni 2021, Hal (32-37)

@Prodi Manajemen Fakultas Ekonomi Universitas Pamulang

reputasi dengan cara menjaga kualitas produknya

3) Diharapkan UMKM seperti produsen peyek Berkah Bersaudara dapat tetap bertahan ditengah terpaan badai wabah Covid-19, UMKM sudah terbukti sebagai salah satu pilar ekonomi Negara Indonesia yang menggerakkan ekonomi bangsa

\section{DAFTAR PUSTAKA}

Haryoko, U. B., Pasaribu, V. L. D., \& Ardiyansyah, A. (2020). PENGARUH HARGA DAN KUALITAS PELAYANAN TERHADAP KEPUASAN KONSUMEN PADA FIRMAN DEKORASI (WEDDING ORGANIZER). POINT, 2(1).

Kotler, Phillip. 2000. Manajemen Pemasaran. Edisi Milenium, Jakarta: PT Indeks Kelompok Gramedia.

Kotler, Phillip. 2005. Manajemen Pemasaran. Jilid 1. Jakarta: PT Indeks Kelompok Gramedia.

Kotler, Philip dan Garry Amstrong. 1997. Prinsip-prinsip Pemasaran. Edisi Ketiga. Jakarta: Erlangga.

R S N Pillai , 2002. Modern Marketing (Principles and Practices) S. Chand \& Company Ltd.

Lindawati. 2005. Analisis Kesadaran Merek, Persepsi Kualitas, dan Asosiasi Merek dalam Ekstensi Merek pada Produk Merek "Lifeboy" di Surabaya. Jurnal Sains Pemasaran Indonesia. Vol. 4 (1). hal. 47-70.

Loudon, David L and Albert J. Della Bitta. 2004. Consumer Behavior Concepts and Appications. Third Edition. Singapore: MC Graw Hill Inc.

Miranti, Ermina. 2004. Prospek Industri Sepeda Motor di Indonesia. Economic Review Journal. No. 198.
Muafi dan M.I. Effendi. 2001. Mengelola Ekuitas Merek: Upaya Memenangkan Persaingan di Era Global. EKOBIS. Vol.2. No.3

Pasaribu, V. L. D. (2020). ANALISIS PENGARUH PROMOSI, KUALITAS PRODUK DAN DESAIN KEMASAN TERHADAP KEPUTUSAN PEMBELIAN HAND AND BODY LOTION MEREK CITRA (Studi Kasus Carrefour Pamulang, Tangerang Selatan). Jurnal Pemasaran Kompetitif, 1(4).

Pasaribu, V. L. D., \& Prayoga, M. Y. S. (2019). Pengaruh Kualitas Produk Baju Batik Hem Terhadap Kepuasan Pelanggan Pada Home Industri Batik Sahara Indah. Jurnal Pemasaran Kompetitif, 2(2), 77-83.

Pasaribu, V. L. D. PENGARUH STORE ATMOSPHERE TERHADAP KEPUTUSAN PEMBELIAN PADA RESTORAN DE'COST GIANT PAMULANG SQUARE TANGERANG SELATAN. Manajerial: Jurnal Manajemen dan Sistem Informasi, 19(2), 156-167.

PASARIBU, V. L. D. (2017). ANALISIS PENGARUH PROMOSI, KUALITAS PRODUK DAN DESAIN KEMASAN TERHADAP PERSEPSI MEREK YANG BERDAMPAK KEPADA KEPUTUSAN PEMBELIAN HAND AND BODY LOTION MEREK VASELINE (Studi Kasus TIP TOP Ciputat, Tangerang Selatan). Inovasi, 4(2).

http://mariaonmarketing.blogspot.com/2012/0 1/pentingnya-harga-dalam-pemasaran.html

https://accurate.id/marketingmanajemen/mengetahui-pentingnyapenetapan-harga-bagi-bisnis/

https://ilmumanajemenpemasaran.wordpress.c om/2009/11/15/pentingnya-kualitas/ 